\title{
Spectroscopy, Photoredox Properties and X-Ray Crystal Structures of Triangular Gold(1) and Silver(I) Phosphine Complexes $\dagger$
}

\author{
Chi-Ming Che,,$^{* a}$ Hon-Kay Yip, ${ }^{a}$ Vivian Wing-Wah Yam, ${ }^{a}$ Pik-Yuk Cheung, ${ }^{a}$ \\ Ting-Fong Lai, ${ }^{a}$ Shen-Jye Shieh ${ }^{b}$ and Shie-Ming Peng ${ }^{b}$ \\ a Department of Chemistry, University of Hong Kong, Pokfulam Road, Hong Kong \\ ${ }^{b}$ Department of Chemistry, National Taiwan University, Taipei, Taiwan
}

\begin{abstract}
The reaction of $\mathrm{HC}\left(\mathrm{PPh}_{2}\right)_{3}$ with $\mathrm{K}\left[\mathrm{AuCl}_{4}\right]$ in the presence of 2,2'-thiodiethanol in methanol yielded $\left[\mathrm{Au}_{3}\left\{\mathrm{HC}\left(\mathrm{PPh}_{2}\right)_{3}\right\}_{2} \mathrm{Cl}\right]^{2+}$. The related $\left[\mathrm{Ag}_{3}\left\{\mathrm{HC}\left(\mathrm{PPh}_{2}\right)_{3}\right\}_{2}\right]^{3+}$ was prepared by the reaction of $\mathrm{HC}\left(\mathrm{PPh}_{2}\right)_{3}$ with $\mathrm{Ag}\left(\mathrm{CF}_{3} \mathrm{SO}_{3}\right)$ in dichloromethane. Both complex cations were isolated as perchlorate salts. The $\mathrm{X}$-ray structures of $\left[\mathrm{Au}_{3}\left\{\mathrm{HC}\left(\mathrm{PPh}_{2}\right)_{3}\right\}_{2} \mathrm{Cl}\right]\left[\mathrm{ClO}_{4}\right]_{2}$ and $\left[\mathrm{Ag}_{3}\left\{\mathrm{HC}\left(\mathrm{PPh}_{2}\right)_{3}\right\}_{2}\right][\mathrm{ClO}]_{3}$ have been determined: $\left[\mathrm{Au}_{3}\left\{\mathrm{HC}\left(\mathrm{PPh}_{2}\right)_{3}\right\}_{2} \mathrm{Cl}\right]\left[\mathrm{ClO}_{4}\right]_{2} \cdot 2 \mathrm{MeCN}$, monoclinic, space group $\mathrm{C2} / \mathrm{c}$ (no. 15), $a=26.466(3), b=$ $12.741(2), c=23.012(5) \AA, \beta=98.89(1)^{\circ}$ and $Z=4 ;\left[\mathrm{Ag}_{3}\left\{\mathrm{HC}\left(\mathrm{PPh}_{2}\right)_{3}\right\}_{2}\right]\left[\mathrm{ClO}_{4}\right]_{3} \cdot 2 \mathrm{MeCN}$, monoclinic, space group, $P 21 / n, a=14.597(4), b=23.047(2), c=22.485(3) \AA, \beta=91.49(2)^{\circ}$ and $Z=4$. Both $\left[\mathrm{Au}_{3}\left\{\mathrm{HC}\left(\mathrm{PPh}_{2}\right)_{3}\right\}_{2} \mathrm{Cl}\right]^{2+}$ and $\left[\mathrm{Ag}_{3}\left\{\mathrm{HC}\left(\mathrm{PPh}_{2}\right)_{3}\right\}_{2}\right]^{3+}$ consist of three metal atoms arranged in a nearly equilateral triangle with the $\mathrm{M}-\mathrm{M}-\mathrm{M}$ angles close to $60^{\circ}$. The measured intramolecular $\mathrm{Ag}-\mathrm{Ag}$ and $\mathrm{Au}-\mathrm{Au}$ distances of $3.1618(5)-3.2228(9)$ and $2.9220(8)-3.0889(8) \AA$ respectively, indicate that the $A u-A u$ bonding interaction is much stronger than that for $\mathrm{Ag}-\mathrm{Ag}$. The UV/VIS spectrum of an acetonitrile solution of $\left[\mathrm{Au}_{3}\left\{\mathrm{HC}\left(\mathrm{PPh}_{2}\right)_{3}\right\}_{2} \mathrm{Cl}\right]^{2+}$ exhibits intense absorption bands at 270 and $290 \mathrm{~nm}$, assignable to the $\mathrm{d}_{\sigma} \cdot \longrightarrow \mathrm{p}_{\sigma}$ transitions. For $\left[\mathrm{Ag}_{3}\left\{\mathrm{HC}\left(\mathrm{PPh}_{2}\right)_{3}\right\}_{2}\right]^{3+}$ the UV/VIS spectrum is virtually identical to that of the free $\mathrm{HC}\left(\mathrm{PPh}_{2}\right)_{3}$. Excitation of a degassed acetonitrile solution of $\left[\mathrm{Au}_{3}\left\{\mathrm{HC}\left(\mathrm{PPh}_{2}\right)_{3}\right\}_{2} \mathrm{Cl}^{2+}\right.$ at $300-$ $400 \mathrm{~nm}$ at room temperature leads to an observed photoluminescence centred at ca. $537 \mathrm{~nm}$ with a lifetime of $11 \mu \mathrm{s}\left[\varphi=(1.0 \pm 0.1) \times 10^{-3}\right]$. The excited-state redox potential, $\left[\mathrm{Au}_{3}\left\{\mathrm{HC}\left(\mathrm{PPh}_{2}\right)_{3}\right\}_{2} \mathrm{Cl}\right]^{3+}$ $+\mathrm{e}^{-} \longrightarrow\left[\mathrm{Au}_{3}\left\{\mathrm{HC}\left(\mathrm{PPh}_{2}\right)_{3}\right\}_{2} \mathrm{Cl}\right]^{2+*}$, determined by quenching studies with a series of pyridinium acceptors, is $-1.6(2) \vee v s$. saturated sodium chloride calomel electrode (SSCE).
\end{abstract}

The design of luminescent metal clusters for photochemical studies has been receiving considerable attention in recent years. Studies in this area was first highlighted by Gray and co-workers ${ }^{1}$ on the basis of their pioneering contribution in the photophysics and photochemistry of $\left[\mathrm{Mo}_{6} \mathrm{X}_{14}\right]^{2-}$ and $\left[\mathrm{W}_{6^{-}}\right.$ $\left.\mathrm{X}_{14}\right]^{2-}$. Recent works by various groups ${ }^{2-5}$ have demonstrated that polymetallic $\mathrm{d}^{10}$ metal complexes exhibit rich photophysical and photochemical properties, in particular, those of dimeric and tetrameric gold(I) were shown to display intense photoluminescence in the solid state and in fluid solutions at room temperature. In an attempt to elucidate the nature of the $\mathrm{d}^{10}-\mathrm{d}^{10}$ interaction which has been suggested to be responsible for the photoluminescence of metal $\mathrm{d}^{10}$ complexes. ${ }^{3.4 a, 6}$ we set forth a program aiming at investigating the synthetic, structural and spectroscopic aspects of different kinds of polymetallic complexes $\left[\left\{\mathrm{M}\left(\mathrm{PR}_{3}\right)_{2}\right\}_{n}\right](\mathrm{M}=\mathrm{Cu}, \mathrm{Ag}$ or $\mathrm{Au})$ with bridging phosphine ligands. The tripodal ligand $\mathrm{L}\left[\mathrm{L}=\mathrm{HC}\left(\mathrm{PPh}_{2}\right)_{3}\right]$ which was reported by Osborn and co-workers ${ }^{7}$ appears to be an ideal ligand for the assembly of triangular metal clusters. Herein we describe the syntheses, spectroscopy and X-ray crystal structures of $\left[\mathrm{Au}_{3}\left\{\mathrm{HC}\left(\mathrm{PPh}_{2}\right)_{3}\right\}_{2} \mathrm{Cl}\right]\left[\mathrm{ClO}_{4}\right]_{2} \cdot 2 \mathrm{MeCN}$ and $\left[\mathrm{Ag}\left\{\mathrm{HC}\left(\mathrm{PPh}_{2}\right)_{3}\right\}_{2}\right]\left[\mathrm{ClO}_{4}\right]_{3} \cdot 2 \mathrm{MeCN}$.

\section{Experimental}

Materials. - The compounds $\mathrm{K}\left[\mathrm{AuCl}_{4}\right]$ and $\mathrm{Ag}\left(\mathrm{CF}_{3} \mathrm{SO}_{3}\right)$ were purchased from Aldrich. The ligand $\mathrm{HC}\left(\mathrm{PPh}_{2}\right)_{3}(\mathrm{~L})$ was

\footnotetext{
+ Supplementary data atailable: see Instructions for Authors, J. Chem Soc., Dalion Trans., 1992, Issue 1, pp. xx-xxv

Non-SI zmit enploved: $\mathrm{eV} \approx 1.60 \times 10^{-19} \mathrm{~J}$.
}

obtained from Strem Chemicals. All solvents and chemicals for photochemical experiments were purified by distillation and recrystallization.

Syntheses. $-\left[\mathrm{Au}_{3} \mathrm{~L}_{2} \mathrm{Cl}\right]\left[\mathrm{ClO}_{4}\right]_{2}$. A methanolic solution $(50$ $\left.\mathrm{cm}^{3}\right)$ of $\mathrm{K}\left[\mathrm{AuCl}_{4}\right](0.3 \mathrm{~g}), \mathrm{L}(0.3 \mathrm{~g})$, and 2,2'-thiodiethanol (1 $\mathrm{cm}^{3}$ ) was heated to $\mathrm{ca} .50{ }^{\circ} \mathrm{C}$ for $30 \mathrm{~min}$. The solution was cooled to room temperature and filtered to remove any undissolved material. The product precipitated from the solution upon addition of solid $\mathrm{LiClO}_{4}$. A pure sample can be obtained by diffusion of diethyl ether into an acetonitrile solution of the product.

$\left[\mathrm{Ag}_{3} \mathrm{~L}_{2}\right][\mathrm{Y}]_{3}\left(\mathrm{Y}=\mathrm{CF}_{3} \mathrm{SO}_{3}\right.$ or $\left.\mathrm{ClO}_{4}\right)$. A dichloromethane solution $(30 \mathrm{~cm})$ of $\mathrm{Ag}\left(\mathrm{CF}_{3} \mathrm{SO}_{3}\right)(0.2 \mathrm{~g})$ and $\mathrm{L}(0.3 \mathrm{~g})$ was heated under reflux for $30 \mathrm{~min}$. The solution was filtered and addition of diethyl ether gave $\left[\mathrm{Ag}_{3} \mathrm{~L}_{2}\right]\left[\mathrm{CF}_{3} \mathrm{SO}_{3}\right]_{3}$. The perchlorate salt was obtained by metathesis with $\mathrm{LiClO}_{4}$ in methanol.

Physical Measurements.-UV/VIS spectra were obtained on a Shimadzu UV-240 spectrophotometer. Emission spectra were measured on a Hitachi 650-60 fluorescence spectrophotometer. Lifetime measurements were conducted with a Quanta-Ray DCR-3 Nd-YAG pulsed laser system. Sample solutions for photochemical experiments were degassed by at least four successive freeze-pump-thaw cycles.

$\mathrm{X}-\mathrm{Ray}$ Crystal Structure of $\left[\mathrm{Au}_{3} \mathrm{~L}_{2} \mathrm{Cl}\right]\left[\mathrm{ClO}_{4}\right]_{2} \cdot 2 \mathrm{MeCN}$ - $\mathrm{X}$-Ray diffraction data were collected on an Enraf-Nonius CAD4 diffractometer with graphite-monochromated Mo-Kx radiation at the University of Hong Kong. The unit-cell dimensions were obtained from a least-squares fit of 25 
Table 1 Crystallographic details for $\left[\mathrm{Au}_{3} \mathrm{~L}_{2} \mathrm{Cl}\right]\left[\mathrm{ClO}_{4}\right]_{2} \cdot 2 \mathrm{MeCN}$ and $\left[\mathrm{Ag}_{3} \mathrm{~L}_{2}\right]\left[\mathrm{ClO}_{4}\right]_{3} \cdot 2 \mathrm{MeCN}$

\begin{tabular}{|c|c|c|}
\hline Empirical formula & {$\left[\mathrm{Au}_{3} \mathrm{~L}_{2} \mathrm{Cl}\right]\left[\mathrm{ClO}_{4}\right]_{2} \cdot 2 \mathrm{MeCN}$} & {$\left[\mathrm{Ag}_{3} \mathrm{~L}_{2}\right]\left[\mathrm{ClO}_{4}\right]_{3} \cdot 2 \mathrm{MeCN}$} \\
\hline$M$ & 2044.51 & 1841.22 \\
\hline$a / \AA$ & $26.466(3)$ & $14.597(4)$ \\
\hline$b / \AA$ & $12.741(2)$ & $23.047(2)$ \\
\hline$c / \AA$ & $23.012(5)$ & $22.485(3)$ \\
\hline$\beta / \%$ & $98.89(1)$ & $91.49(2)$ \\
\hline$U / \AA^{3}$ & $7667(4)$ & $7562(3)$ \\
\hline$F(000)$ & 3968 & 3712 \\
\hline Space group & $C 2 / c$ (no. 15$)$ & $P 2_{1} / n($ no. 14$)$ \\
\hline$D_{\mathrm{c}} / \mathrm{Mg} \mathrm{m}^{-3}$ & 1.771 & 1.62 \\
\hline$D_{\mathrm{m}} / \mathrm{Mg} \mathrm{m}^{-3}$ & 1.76 & - \\
\hline$\mu / \mathrm{cm}^{-1}$ & 60.0 & 10.5 \\
\hline Crystal colour/shape & Bright yellow, Prisms & Colourless, Prisms \\
\hline Crystal dimensions $/ \mathrm{mm}$ & $0.05 \times 0.11 \times 0.17$ & $0.25 \times 0.30 \times 0.50$ \\
\hline $2 \theta_{\max } /^{\circ}$ & 48 & 45 \\
\hline Scan speed $/{ }^{\circ} \mathrm{min}^{-1}$ & $1.26-5.49$ & $1.65-8.24$ \\
\hline Scan width $/^{\circ}$ & $0.80 \pm 0.34 \tan \theta$ & $0.65 \pm 0.35 \tan \theta$ \\
\hline Independent reflections & 6312 & 9850 \\
\hline Observed reflections, $N$ & $4131[F>3 \sigma(F)]$ & $8011[I>2 \sigma(I)]$ \\
\hline No. of parameters, $P$ & 241 & 938 \\
\hline$R^{*}$ & 0.051 & 0.037 \\
\hline$R^{\prime}$ & 0.055 & 0.038 \\
\hline Weighting scheme & $w^{\prime}=4 F^{2} /\left[\sigma^{2}\left(F^{2}\right)+\left(0.055 F^{2}\right)^{2}\right]$ & $n^{-1}=\sigma^{2}(F)+0.0001 F^{2}$ \\
\hline$S^{*}$ & 1.23 & 1.85 \\
\hline $\begin{array}{l}\text { Residual extrema in final } \\
\text { difference map } / \mathrm{e} \AA^{-3}\end{array}$ & $-1.41,+1.73$ & $-0.43,+0.47$ \\
\hline
\end{tabular}

Details in common: crystal system monoclinic, $Z=4$, scan mode $\omega-2 \theta$, indices collected $h, k, \pm l$.

${ }^{*} R=\Sigma\left\|F_{\mathrm{o}}|-| F_{\mathrm{c}}\right\| / \Sigma F_{\mathrm{o}} \mid, R^{\prime}=\left[w\left(\left|F_{\mathrm{o}}\right|-\left|F_{\mathrm{c}}\right|\right)^{2} / \Sigma w\left|F_{\mathrm{o}}\right|^{2}\right]^{\frac{1}{2}}, S=\left[\Sigma w\left(\left|F_{\mathrm{o}}\right|-\left|F_{\mathrm{c}}\right|\right)^{2} /(N-P)\right]^{\frac{1}{2}}$.

reflections in the range $19<2 \theta<28^{\circ}$. Three check reflections monitored every $2 \mathrm{~h}$ showed a gradual drop in intensity to a maximum of $13.8 \%$. The data were corrected for Lorentz, polarization and linear decay effects. No Absorption correction was made.* Crystallographic data are summarized in Table 1. Atomic scattering factors are taken from ref. 8. Calculations were carried out on a MICROVAX II computer using the Enraf-Nonius SDP programs. ${ }^{9}$

The positions of the gold and phosphorus atoms were determined from a Patterson function and the rest of the nonhydrogen atoms were found from subsequent Fourier maps. The hydrogen atoms of the metal complex were generated geometrically ( $\mathrm{C}-\mathrm{H} \quad 0.95 \AA$ ), while those of the solvent molecule were omitted. Refinement was by full-matrix least squares: the gold, chlorine and phosphorus atoms were refined anisotropically and all other non-hydrogen atoms isotropically. The hydrogen atoms with assigned isotropic thermal parameters were not refined. Both the perchlorate ion and the solvent molecule were badly disordered. The final agreement factors are given in Table 1 and atomic coordinates of nonhydrogen atoms are listed in Table 2 . Selected bond distances and angles are summarized in Table 3.

$X$-Ray Crystal Structure of $\left[\mathrm{Ag}_{3} \mathrm{~L}_{2}\right]\left[\mathrm{ClO}_{4}\right]_{3} \cdot 2 \mathrm{MeCN}-\mathrm{X}$ Ray diffraction data were collected on an Enraf-Nonius CAD-4 four-circle diffractometer (graphite-monochromatized Mo-K $\alpha$ radiation) using the $\theta-2 \theta$ scan mode at the National Taiwan University. The unit-cell dimensions were obtained from a least-squares fit of 25 reflections in the range $14<2 \theta<33^{\circ}$. The data were corrected for absorption. Crystallographic data are summarized in Table 1 . All data reduction and structure refinement were performed using the NRCC-SDP-VAX packages available from S.-M. Peng on request. The structure

* An attempt to correct for absorption by an empirical method was also made. Comparison of the two sets of results, that is, with and without absorption correction, showed no significant difference in bond lengths and angles; however, the residual electron densities near the Au atoms were slightly higher in the former, hence the data set without absorption are reported. was solved by the Patterson method and refined by least squares. The final agreement factors are given in Table 1. Atomic coordinates of non-hydrogen atoms are listed in Table 4 and selected bond distances and angles in Table 5 .

Additional material available from the Cambridge Crystallographic Data Centre comprises $\mathrm{H}$-atom coordinates, thermal parameters and remaining bond lengths and angles.

\section{Results and Discussion}

The ligand $\mathrm{HC}\left(\mathrm{PPh}_{2}\right)_{3}(\mathrm{~L})$ was first employed by Osborn and co-workers ${ }^{7}$ for the synthesis of polymetallic complexes. Transition-metal complexes having three metal atoms simultaneously bound to the three phosphorus atoms of $L$ have been synthesized and structurally characterized as in the case of $\left[\mathrm{Ag}_{6}\left\{\mathrm{Fe}(\mathrm{CO})_{4}\right\}_{3}\left\{\mathrm{HC}\left(\mathrm{PPh}_{2}\right)_{3}\right\}\right] .{ }^{10}$ Recently, we have reported the formation of linear trinuclear silver(I) ${ }^{11 a}$ and gold(I) ${ }^{2 a}$ complexes with $\mathrm{Ph}_{2} \mathrm{PCH}_{2} \mathrm{P}(\mathrm{Ph}) \mathrm{CH}_{2} \mathrm{PPh}_{2}$ and $\mathrm{Me}_{2} \mathrm{PCH}_{2}-$ $\mathrm{P}(\mathrm{Me}) \mathrm{CH}_{2} \mathrm{PMe}_{2}$ ligands, respectively. In this work, the reaction of $\mathrm{L}$ with $\mathrm{Au}^{\mathbf{l}}$, generated in situ by the reduction of $\left[\mathrm{AuCl}_{4}\right]^{-}$with 2,2'-thiodiethanol, or $\mathrm{Ag}^{\mathrm{l}}$ gave trimeric bis(triphosphine)metal complexes with the three metal atoms arranged in a triangular array. The extremely low solubility of $\left[\mathrm{Au}_{3} \mathrm{~L}_{2} \mathrm{Cl}\right]\left[\mathrm{ClO}_{4}\right]_{2}$ in most common organic solvents precludes the recording of its ${ }^{31} \mathrm{P}$ NMR spectrum. Although $\mathrm{L}$ appears to be a stable ligand at room temperature, our attempt to prepare $\left[\mathrm{Au}_{3} \mathrm{~L}_{2}\right]^{3+}$ either by prolonged heating of $\left[\mathrm{AuCl}_{4}\right]^{-}$and $\mathrm{L}$ in the presence of $2,2^{\prime}$-thiodiethanol in methanol, or by reaction of $\left[\mathrm{Au}_{3} \mathrm{~L}_{2} \mathrm{Cl}\right]^{2+}$ with $\mathrm{Ag}^{\mathrm{I}}$ in acetonitrile or methanol at ca. $50 \mathrm{C}$, afforded the colourless $\left[\mathrm{Au}_{2}(\mathrm{dppm})_{2}\right]^{2+}$ complex $[\mathrm{dppm}=$ bis(diphenylphosphino)methane], which has been characterized by its UV/VIS absorption and emission properties as well as Xray crystallography. ${ }^{11 \mathrm{~h}}$ It appears that the $\mathrm{Au}^{1}$ or $\mathrm{Au}^{\mathrm{III}}$ ion promotes cleavage of the $\mathrm{P}-\mathrm{C}$ bond in $\mathrm{L}$ in protic solvents or at high temperature [equation (1)]. To our knowledge, such a

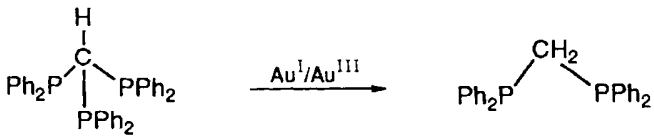


Table 2 Positional coordinates of non-hydrogen atoms in $\left[\mathrm{Au}_{3} \mathrm{~L}_{2} \mathrm{Cl}\right][\mathrm{ClO}]_{4} \cdot 2 \mathrm{MeCN}$ with estimated standard deviations (e.s.d.s) in parentheses

\begin{tabular}{|c|c|c|c|c|c|c|c|}
\hline Atom & $x$ & $y$ & $z$ & Atom & $x$ & $y$ & $z$ \\
\hline $\mathrm{Au}(1)$ & $0.02249(2)$ & $0.43541(4)$ & $0.19587(2)$ & $\mathrm{C}(21)$ & $0.2062(5)$ & $0.413(1)$ & $0.2431(6)$ \\
\hline $\mathrm{Au}(2)$ & 0.000 & $0.64900(5)$ & 0.250 & $\mathrm{C}(22)$ & $0.2468(6)$ & $0.420(1)$ & $0.2107(7)$ \\
\hline $\mathrm{Cl}(1)$ & 0.000 & $0.8564(5)$ & 0.250 & $C(23)$ & $0.2341(6)$ & $0.439(1)$ & $0.1530(7)$ \\
\hline$P(1)$ & $-0.0560(1)$ & $0.4505(3)$ & $0.1357(1)$ & $C(24)$ & $0.1862(7)$ & $0.455(1)$ & $0.1249(8)$ \\
\hline$P(2)$ & $0.1009(1)$ & $0.4067(2)$ & $0.2536(1)$ & $C(25)$ & $0.1465(5)$ & $0.447(1)$ & $0.1560(6)$ \\
\hline$P(3)$ & $-0.0864(1)$ & $0.6330(2)$ & $0.2077(1)$ & $C(26)$ & $-0.1091(4)$ & $0.719(1)$ & $0.1454(5)$ \\
\hline$C(1)$ & $-0.1053(4)$ & $0.4965(9)$ & $0.1817(5)$ & $C(27)$ & $-0.1597(5)$ & $0.716(1)$ & $0.1193(6)$ \\
\hline $\mathrm{C}(2)$ & $-0.0776(4)$ & $0.3318(9)$ & $0.0957(5)$ & $\mathrm{C}(28)$ & $-0.1756(6)$ & $0.789(1)$ & $0.0726(7)$ \\
\hline$C(3)$ & $-0.1242(5)$ & $0.330(1)$ & $0.0559(6)$ & $C(29)$ & $-0.1425(6)$ & $0.857(1)$ & $0.0567(7)$ \\
\hline$C(4)$ & $-0.1365(5)$ & $0.240(1)$ & $0.0235(6)$ & $C(30)$ & $-0.0931(6)$ & $0.858(1)$ & $0.0816(8)$ \\
\hline$C(5)$ & $-0.1032(6)$ & $0.155(1)$ & $0.0272(7)$ & $C(31)$ & $-0.0741(5)$ & $0.789(1)$ & $0.1266(6)$ \\
\hline$C(6)$ & $-0.0590(6)$ & $0.158(1)$ & $0.0667(7)$ & $\mathrm{C}(32)$ & $-0.1257(4)$ & $0.6695(9)$ & $0.2623(5)$ \\
\hline$C(7)$ & $-0.0462(5)$ & $0.246(1)$ & $0.1009(6)$ & $C(33)$ & $-0.1020(6)$ & $0.711(1)$ & $0.3146(8)$ \\
\hline$C(8)$ & $-0.0526(4)$ & $0.5461(9)$ & $0.0780(5)$ & $C(34)$ & $-0.1316(8)$ & $0.747(2)$ & $0.3570(9)$ \\
\hline$C(9)$ & $-0.0036(5)$ & $0.585(1)$ & $0.0709(6)$ & $C(35)$ & $-0.1843(8)$ & $0.738(2)$ & $0.3444(9)$ \\
\hline$C(10)$ & $0.0007(6)$ & $0.652(1)$ & $0.0249(7)$ & $C(36)$ & $-0.2074(6)$ & $0.693(1)$ & $0.2947(7)$ \\
\hline$C(11)$ & $-0.0420(6)$ & $0.684(1)$ & $-0.0115(7)$ & $C(37)$ & $-0.1791(5)$ & $0.658(1)$ & $0.2527(6)$ \\
\hline$C(12)$ & $-0.0879(6)$ & $0.644(1)$ & $-0.0061(7)$ & $\mathrm{Cl}(2)$ & $0.2519(2)$ & $0.4733(6)$ & $0.4424(2)$ \\
\hline$C(13)$ & $-0.0944(5)$ & $0.577(1)$ & $0.0378(6)$ & $O(1)$ & $0.2213(5)$ & $0.471(1)$ & $0.3891(6)$ \\
\hline$C(14)$ & $0.1076(4)$ & $0.272(1)$ & $0.2791(5)$ & $O(2)$ & $0.3012(5)$ & $0.464(1)$ & $0.4429(6)$ \\
\hline$C(15)$ & $0.1492(5)$ & $0.241(1)$ & $0.3199(6)$ & $O(3)$ & $0.2283(7)$ & $0.509(2)$ & $0.4857(9)$ \\
\hline$C(16)$ & $0.1544(6)$ & $0.137(1)$ & $0.3365(7)$ & $\mathrm{O}(4 \mathrm{~A})^{*}$ & $0.245(1)$ & $0.348(3)$ & $0.457(1)$ \\
\hline$C(17)$ & $0.1202(7)$ & $0.065(1)$ & $0.3110(8)$ & $O(4 B)^{*}$ & $0.268(2)$ & $0.605(4)$ & $0.433(2)$ \\
\hline$C(18)$ & $0.0786(7)$ & $0.094(1)$ & $0.2716(8)$ & $\mathrm{N}$ & $0.082(2)$ & $0.058(4)$ & $0.107(2)$ \\
\hline$C(19)$ & $0.0720(6)$ & $0.199(1)$ & $0.2549(7)$ & $C(38)$ & $0.169(1)$ & $0.130(3)$ & $0.158(2)$ \\
\hline$C(20)$ & $0.1562(4)$ & $0.427(1)$ & $0.2172(5)$ & $C(39)$ & $0.113(1)$ & $0.132(3)$ & $0.123(2)$ \\
\hline
\end{tabular}

* Occupancy factor $=0.5$.

Table 3 Selected interatomic distances $(\AA)$ and angles $\left({ }^{\circ}\right)$ for $\left[\mathrm{Au}_{3} \mathrm{~L}_{2} \mathrm{Cl}\right]\left[\mathrm{ClO}_{4}\right]_{2} \cdot 2 \mathrm{MeCN}$ with e.s.d.s in parentheses*

$\begin{array}{llll}\mathrm{Au}(1)-\mathrm{Au}\left(1^{\prime}\right) & 2.9220(8) & \mathrm{P}(1)-\mathrm{C}(8) & 1.81(1) \\ \mathrm{Au}(1)-\mathrm{Au}(2) & 3.0889(8) & \mathrm{P}(2)-\mathrm{C}\left(1^{\prime}\right) & 1.87(1) \\ \mathrm{Au}(1)-\mathrm{P}(1) & 2.318(3) & \mathrm{P}(2)-\mathrm{C}(14) & 1.82(1) \\ \mathrm{Au}(1)-\mathrm{P}(2) & 2.313(3) & \mathrm{P}(2)-\mathrm{C}(20) & 1.81(1) \\ \mathrm{Au}(2)-\mathrm{Cl}(1) & 2.642(6) & \mathrm{P}(3)-\mathrm{C}(1) & 1.88(1) \\ \mathrm{Au}(2)-\mathrm{P}(3) & 2.351(3) & \mathrm{P}(3)-\mathrm{C}(26) & 1.84(1) \\ \mathrm{P}(1)-\mathrm{C}(1) & 1.90(1) & \mathrm{P}(3)-\mathrm{C}(32) & 1.81(1)\end{array}$

$\mathrm{P}(1)-\mathrm{C}(2)$

$\mathrm{Au}\left(1^{\prime}\right)-\mathrm{Au}(1)-\mathrm{Au}(2) \quad 61.77(1)$

$\mathrm{Au}(1)-\mathrm{Au}(2)-\mathrm{Au}\left(1^{\prime}\right) \quad 56.46(2)$

$\mathrm{P}(1)-\mathrm{Au}(1)-\mathrm{P}(2) \quad 175.6(1)$

$\mathrm{P}(3)-\mathrm{Au}(2)-\mathrm{P}\left(3^{\prime}\right) \quad 170.1(1)$

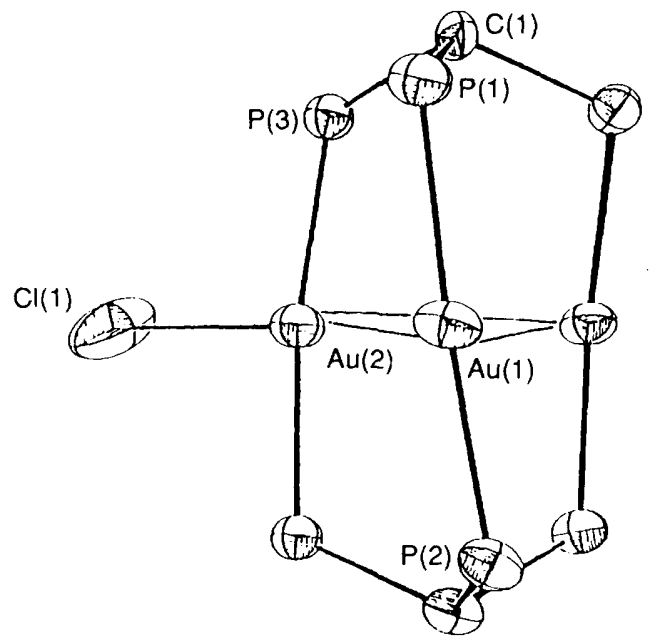

Fig. I ORTEP plot of the $\left[\mathrm{Au}_{3} \mathrm{~L}_{2} \mathrm{Cl}\right]^{2+}$ cation with atomic numbering. The phenyl carbons are not shown for clarity reaction pathway has not been reported in gold chemistry but a similar process has recently been observed in the reaction of $\left[\mathrm{Ru}_{3}(\mathrm{CO})_{12}\right]$ with L. ${ }^{12}$

The structures of $\left[\mathrm{Au}_{3} \mathrm{~L}_{2} \mathrm{Cl}\right]^{2+} 1$ and $\left[\mathrm{Ag}_{3} \mathrm{~L}_{2}\right]^{3+} 2$ have been established by $X$-ray crystallography. Fig. 1 shows the ORTEP plot of the core of $\left[\mathrm{Au}_{3} \mathrm{~L}_{2} \mathrm{Cl}\right]^{2+}$ ion with atomic numbering. One of the gold atoms [Au(2)] and the chloride ligand lie on a crystallographic two-fold axis with half a cation in an asymmetric unit and the other half generated by the two-fold axis. Except for the $\mathrm{Au}(2)$ atom which is three co-ordinated, the $\mathrm{Au}(1)$ and $\mathrm{Au}\left(1^{\prime}\right)$ atoms are linearly co-ordinated to two phosphorus atoms with the measured $\mathrm{P}-\mathrm{Au}-\mathrm{P}$ angles close to $180^{\circ}$ [e.g. $\mathrm{P}(1)-\mathrm{Au}(1)-\mathrm{P}(2) 175.6(1)^{\circ}$ ]. The co-ordination geometry about the $\mathrm{Au}(2)$ atom is very similar to that found for the gold atoms in $\left[\mathrm{Au}_{2}(\mathrm{dppm})_{2} \mathrm{Cl}_{2}\right]^{13}$ in that the $\mathrm{Au}-\mathrm{Cl}$ bond is nearly perpendicular to the $\mathrm{P}-\mathrm{Au}-\mathrm{P}$ axis $\{\mathrm{Cl}-\mathrm{Au}-\mathrm{P}$ 94.97(8) $\left.1 ; 115.7(1)^{\circ}\left[\mathrm{Au}_{2}(\mathrm{dppm})_{2} \mathrm{Cl}_{2}\right]\right\}$. The $\mathrm{P}(3)-\mathrm{Au}-\mathrm{P}\left(3^{\prime}\right)$ axis is also approximately linear with a measured $\mathrm{P}(3)-\mathrm{Au}-\mathrm{P}\left(3^{\prime}\right)$ angle of $170.0(1)^{\circ}$. The $\mathrm{Au}(2)-\mathrm{Cl}$ distance of 2.642(6) $\AA$ is significantly shorter than the value of 2.771(4) $\AA$ found in $\left[\mathrm{Au}_{2}(\mathrm{dppm})_{2} \mathrm{Cl}_{2}\right] ;{ }^{13}$ presumably this is due to the higher formal charge on the trinuclear gold(1) complex. The $\mathrm{Au}(2)$, $\mathrm{Au}(1)$ and $\mathrm{Au}\left(1^{\prime}\right)$ atoms, similarly to the three phosphorus atoms of the tripodal ligand, are arranged in a nearly equilateral triangle with the $\mathrm{Au}-\mathrm{Au}-\mathrm{Au}$ angles close to $60^{\circ}$, substantially smaller than that of $136.26(4)^{\circ}$ found in $\left[\mathrm{Au}_{3}(\mathrm{dmmp})_{2}\right]^{3+}$ [dmmp $=$ bis(dimethylphosphinomethyl)methylphosphine $]^{2 a}$ and $110.9(1)^{\circ}$ in $\left[\mathrm{Au}_{3} \mathrm{Cl}_{3}(\mu-\mathrm{dpma})\right]$ [dpma = bis(diphenylphosphinomethyl)phenylarsine.$^{5}$ An interesting observation is that co-ordination of chloride to the gold atom $\mathrm{Au}(2)$ results in an increase in the intramolecular $\mathrm{Au}-\mathrm{Au}$ distance. For example, the $\mathrm{Au}(1)-\mathrm{Au}\left(1^{\prime}\right)$ distance of $2.9220(8)$ is about $0.167 \AA$ shorter than that for $\mathrm{Au}(1)-\mathrm{Au}(2)$ or $\mathrm{Au}\left(1^{\prime}\right)-\mathrm{Au}(2)$. Similar findings can also be observed by comparison of X-ray crystal data for $\left[\mathrm{Au}_{2}(\mathrm{dppm})_{2}\right]\left[\mathrm{BF}_{4}\right]_{2}[d(\mathrm{Au}-\mathrm{Au})=2.931(1) \AA]^{14}$ and $\left[\mathrm{Au}_{2}(\mathrm{dppm})_{2} \mathrm{Cl}_{2}\right][d(\mathrm{Au}-\mathrm{Au})=3.028(2) \AA] .{ }^{13}$ Recent work by Mason and co-workers ${ }^{15}$ also established that the interatomic $\mathrm{Au}-\mathrm{Au}$ distances of $\left[\mathrm{Au}_{2}(\mathrm{dmpe})_{2}\right] \mathrm{X}_{2}$ increase in the order: $\mathrm{X}=\mathrm{ClO}_{4}<\mathrm{Cl}<\mathrm{Br}<\mathrm{I}$. The Au-P distances of 2.313(3)2.351(3) $\AA$ are in the usual range. The co-ordination geometry 
Table 4 Positional coordinates for non-hydrogen atoms in $\left[\mathrm{Ag}_{3} \mathrm{~L}_{2}\right]\left[\mathrm{ClO}_{4}\right]_{3} \cdot 2 \mathrm{MeCN}$ with e.s.d.s in parentheses

\begin{tabular}{|c|c|c|c|c|c|c|c|}
\hline Atom & $x$ & $y$ & $z$ & Atom & $x$ & $y$ & $z$ \\
\hline $\mathrm{Ag}(1)$ & $0.62654(3)$ & $0.29868(2)$ & $0.03531(2)$ & $C(6 G)$ & $0.7740(4)$ & $0.4232(2)$ & $0.0297(2)$ \\
\hline $\operatorname{Ag}(2)$ & $0.81076(3)$ & $0.23195(2)$ & $-0.00122(1)$ & $\mathrm{C}(1 \mathrm{H})$ & $0.5677(4)$ & $0.4120(2)$ & $-0.0709(2)$ \\
\hline $\operatorname{Ag}(3)$ & $0.61536(2)$ & $0.18531(1)$ & $-0.04374(1)$ & $\mathrm{C}(2 \mathrm{H})$ & $0.5734(4)$ & $0.4468(2)$ & $-0.1212(2)$ \\
\hline$P(1)$ & $0.60456(8)$ & $0.23197(5)$ & $0.11742(5)$ & $\mathrm{C}(3 \mathrm{H})$ & $0.5071(4)$ & $0.4864(2)$ & $-0.1353(3)$ \\
\hline$P(2)$ & $0.80258(8)$ & $0.19460(5)$ & $0.09940(5)$ & $\mathrm{C}(4 \mathrm{H})$ & $0.4329(4)$ & $0.4917(2)$ & $-0.0989(3)$ \\
\hline$P(3)$ & $0.64613(8)$ & $0.12454(5)$ & $0.04472(5)$ & $\mathrm{C}(5 \mathrm{H})$ & $0.4255(4)$ & $0.4582(3)$ & $-0.0496(3)$ \\
\hline$P(4)$ & $0.65925(8)$ & $0.36301(5)$ & $-0.04711(5)$ & $\mathrm{C}(6 \mathrm{H})$ & $0.4935(3)$ & $0.4177(2)$ & $-0.0350(2)$ \\
\hline$P(5)$ & $0.80687(8)$ & $0.28264(5)$ & $-0.09598(5)$ & $C(1 I)$ & $0.8994(3)$ & $0.3345(2)$ & $-0.1044(2)$ \\
\hline$P(6)$ & $0.60692(8)$ & $0.25989(5)$ & $-0.12348(5)$ & $\mathrm{C}(2 \mathrm{I})$ & $0.9096(3)$ & $0.3673(2)$ & $-0.1558(2)$ \\
\hline$C(1)$ & $0.6831(3)$ & $0.1684(2)$ & $0.1116(2)$ & $C(3 I)$ & $0.9879(3)$ & $0.4006(2)$ & $-0.1627(2)$ \\
\hline$C(2)$ & $0.6940(3)$ & $0.3194(2)$ & $-0.1128(2)$ & $C(4 I)$ & $1.0556(3)$ & $0.3995(2)$ & $-0.1192(3)$ \\
\hline$C(1 \mathrm{~A})$ & $0.4885(3)$ & $0.2028(2)$ & $0.1175(2)$ & $\mathrm{C}(5 \mathrm{I})$ & $1.0456(3)$ & $0.3680(2)$ & $-0.0684(2)$ \\
\hline$C(2 A)$ & $0.4257(3)$ & $0.2229(2)$ & $0.0755(2)$ & $C(6 \mathrm{I})$ & $0.9671(3)$ & $0.3355(2)$ & $-0.0603(2)$ \\
\hline$C(3 A)$ & $0.3357(4)$ & $0.2035(3)$ & $0.0758(3)$ & $C(1 J)$ & $0.8277(3)$ & $0.2317(2)$ & $-0.1563(2)$ \\
\hline$C(4 A)$ & $0.3090(4)$ & $0.1638(3)$ & $0.1172(3)$ & $\mathrm{C}(2 \mathrm{~J})$ & $0.8283(3)$ & $0.2484(2)$ & $-0.2158(2)$ \\
\hline$C(5 A)$ & $0.3704(4)$ & $0.1447(2)$ & $0.1593(2)$ & $C(3 J)$ & $0.8522(3)$ & $0.2088(2)$ & $-0.2585(2)$ \\
\hline$C(6 A)$ & $0.4594(3)$ & $0.1634(2)$ & $0.1600(2)$ & $C(4 J)$ & $0.8751(4)$ & $0.1527(2)$ & $-0.2424(2)$ \\
\hline$C(1 B)$ & $0.6184(3)$ & $0.2628(2)$ & $0.1913(2)$ & $C(5 J)$ & $0.8748(4)$ & $0.1361(2)$ & $-0.1843(2)$ \\
\hline$C(2 B)$ & $0.6231(3)$ & $0.3225(2)$ & $0.1956(2)$ & $C(6 J)$ & $0.8524(3)$ & $0.1756(2)$ & $-0.1407(2)$ \\
\hline$C(3 B)$ & $0.6227(4)$ & $0.3488(2)$ & $0.2519(2)$ & $\mathrm{C}(1 \mathrm{~K})$ & $0.6150(3)$ & $0.2353(2)$ & $-0.2001(2)$ \\
\hline$C(4 B)$ & $0.6153(4)$ & $0.3146(3)$ & $0.3014(2)$ & $\mathrm{C}(2 \mathrm{~K})$ & $0.6113(3)$ & $0.2732(2)$ & $-0.2481(2)$ \\
\hline$C(5 B)$ & $0.6129(4)$ & $0.2557(3)$ & $0.2978(2)$ & $\mathrm{C}(3 \mathrm{~K})$ & $0.6089(4)$ & $0.2514(3)$ & $-0.3057(2)$ \\
\hline$C(6 B)$ & $0.6153(3)$ & $0.2291(2)$ & $0.2426(2)$ & $C(4 K)$ & $0.6101(4)$ & $0.1935(3)$ & $-0.3153(2)$ \\
\hline$C(1 C)$ & $0.8788(3)$ & $0.1378(2)$ & $0.1268(2)$ & $C(5 K)$ & $0.6166(4)$ & $0.1556(3)$ & $-0.2687(3)$ \\
\hline$C(2 C)$ & $0.9628(3)$ & $0.1321(2)$ & $0.0999(2)$ & $\mathrm{C}(6 \mathrm{~K})$ & $0.6191(3)$ & $0.1760(2)$ & $-0.2100(2)$ \\
\hline$C(3 C)$ & $1.0269(3)$ & $0.0935(3)$ & $0.1246(3)$ & $C(1 L)$ & $0.4936(3)$ & $0.2927(2)$ & $-0.1214(2)$ \\
\hline$C(4 C)$ & $1.0077(4)$ & $0.0609(2)$ & $0.1734(3)$ & $C(2 L)$ & $0.4600(3)$ & $0.3333(2)$ & $-0.1627(2)$ \\
\hline$C(5 C)$ & $0.9247(4)$ & $0.0663(2)$ & $0.1992(2)$ & $\mathrm{C}(3 \mathrm{~L})$ & $0.3701(4)$ & $0.3533(2)$ & $-0.1599(2)$ \\
\hline$C(6 C)$ & $0.8601(3)$ & $0.1046(2)$ & $0.1769(2)$ & $C(4 L)$ & $0.3145(4)$ & $0.3319(3)$ & $-0.1163(3)$ \\
\hline$C(1 D)$ & $0.8280(3)$ & $0.2535(2)$ & $0.1513(2)$ & $C(5 L)$ & $0.3453(4)$ & $0.2929(2)$ & $-0.0763(3)$ \\
\hline$C(2 D)$ & $0.8474(3)$ & $0.3079(2)$ & $0.1288(2)$ & $C(6 L)$ & $0.4347(3)$ & $0.2729(2)$ & $-0.0785(2)$ \\
\hline$C(3 D)$ & $0.8708(4)$ & $0.3527(2)$ & $0.1668(2)$ & $C(11)$ & $0.59626(10)$ & $0.29422(7)$ & $0.48633(6)$ \\
\hline$C(4 D)$ & $0.8775(4)$ & $0.3432(2)$ & $0.2266(2)$ & $C(12)$ & $0.80584(10)$ & $0.51082(6)$ & $0.23285(6)$ \\
\hline$C(5 D)$ & $0.8611(3)$ & $0.2895(2)$ & $0.2497(2)$ & $C(13)$ & $0.25780(10)$ & $0.51903(7)$ & $0.24957(6)$ \\
\hline$C(6 D)$ & $0.8369(3)$ & $0.2446(2)$ & $0.2121(2)$ & $O(1)$ & $0.6481(3)$ & $0.2672(2)$ & $0.4428(2)$ \\
\hline $\mathrm{C}(1 \mathrm{E})$ & $0.5548(3)$ & $0.0778(2)$ & $0.0701(2)$ & $O(2)$ & $0.5042(3)$ & $0.3016(2)$ & $0.4659(2)$ \\
\hline$C(2 E)$ & $0.5615(3)$ & $0.046 \mathrm{I}(2)$ & $0.1225(2)$ & $O(3)$ & $0.6359(3)$ & $0.3466(2)$ & $0.5053(3)$ \\
\hline$C(3 E)$ & $0.4915(4)$ & $0.0107(2)$ & $0.1393(2)$ & $O(4)$ & $0.5940(4)$ & $0.2517(3)$ & $0.5364(2)$ \\
\hline$C(4 E)$ & $0.4149(4)$ & $0.0056(2)$ & $0.1040(2)$ & $O(5)$ & $0.8918(3)$ & $0.4875(2)$ & $0.2168(2)$ \\
\hline$C(5 E)$ & $0.4066(3)$ & $0.0363(2)$ & $0.0526(2)$ & $O(6)$ & $0.7451(4)$ & $0.5032(3)$ & $0.1863(2)$ \\
\hline$C(6 E)$ & $0.4764(3)$ & $0.0719(2)$ & $0.0348(2)$ & $O(7)$ & $0.8166(3)$ & $0.5720(2)$ & $0.2449(2)$ \\
\hline$C(1 F)$ & $0.7389(3)$ & $0.0747(2)$ & $0.0293(2)$ & $\mathrm{O}(8)$ & $0.7759(3)$ & $0.4831(2)$ & $0.2844(2)$ \\
\hline$C(2 F)$ & $0.7741(3)$ & $0.0756(2)$ & $-0.0279(2)$ & $\mathrm{O}(9)$ & $0.3198(4)$ & $0.4835(2)$ & $0.2216(2)$ \\
\hline$C(3 F)$ & $0.8420(4)$ & $0.0358(3)$ & $-0.0430(2)$ & $O(10)$ & $0.2769(3)$ & $0.5785(2)$ & $0.2338(2)$ \\
\hline$C(4 F)$ & $0.8740(4)$ & $-0.0036(2)$ & $-0.0021(3)$ & $O(11)$ & $0.1680(4)$ & $0.5063(3)$ & $0.2334(3)$ \\
\hline$C(5 F)$ & $0.8398(3)$ & $-0.0059(2)$ & $0.0539(2)$ & $O(12)$ & $0.2691(3)$ & $0.5124(2)$ & $0.3113(2)$ \\
\hline $\mathrm{C}(6 \mathrm{~F})$ & $0.7711(3)$ & $0.0338(2)$ & $0.0696(2)$ & $C(3)$ & $0.8053(4)$ & $0.3793(3)$ & $0.3876(3)$ \\
\hline$C(1 G)$ & $0.7511(3)$ & $0.4137(2)$ & $-0.0295(2)$ & $C(4)$ & $0.9040(4)$ & $0.3707(2)$ & $0.3927(2)$ \\
\hline$C(2 G)$ & $0.7922(3)$ & $0.4465(2)$ & $-0.0732(2)$ & $N(1)$ & $0.9801(3)$ & $0.3636(2)$ & $0.3985(2)$ \\
\hline$C(3 G)$ & $0.8569(3)$ & $0.4883(2)$ & $-0.0571(3)$ & $C(5)$ & $0.2904(6)$ & $0.3902(5)$ & $0.1000(4)$ \\
\hline$C(4 G)$ & $0.8794(4)$ & $0.4972(2)$ & $0.0019(3)$ & $C(6)$ & $0.3859(5)$ & $0.3730(3)$ & $0.0979(3)$ \\
\hline$C(5 G)$ & $0.8371(4)$ & $0.4658(2)$ & $0.0457(2)$ & $\mathrm{N}(2)$ & $0.4596(4)$ & $0.3598(2)$ & $0.0964(2)$ \\
\hline
\end{tabular}

of the tripodal ligand is normal; the $\mathrm{P}-\mathrm{C}-\mathrm{P}$ angles are close to $108^{\circ}$ as expected for $\mathrm{a} \mathrm{sp}^{3}$ hybridized carbon atom. ${ }^{7,10}$

Fig. 2 shows the ORTEP plot of the $\left[\mathrm{Ag}_{3} \mathrm{~L}_{2}\right]^{3+}$ cation with atomic numbering. Except for the absence of a co-ordinated chloride and the presence of two weakly co-ordinated acetonitrile ligands, it is structurally similar to $\left[\mathrm{Au}_{3} \mathrm{~L}_{2} \mathrm{Cl}\right]^{2+}$ described above. Each silver atom is essentially in a linear two-coordinated geometry with the $\mathrm{P}-\mathrm{Ag}-\mathrm{P}$ angles ranging from $168.59(4)$ to $176.08(4)^{\circ}$. The two acetonitrile molecules weakly co-ordinate to $\operatorname{Ag}(1)$ and $\operatorname{Ag}(3)$ with the measured $\operatorname{Ag}(1)-\mathrm{N}(2)$ and $\mathrm{Ag}(3)-\mathrm{N}(1)$ distances being 3.161(6) and 2.592(4) $\AA$, respectively. As in the cases of $\left[\mathrm{Au}_{3} \mathrm{~L}_{2} \mathrm{Cl}\right]^{2+}$ and $\left[\mathrm{Ag}_{6}\left\{\mathrm{Fe}(\mathrm{CO})_{4}\right\}_{3^{-}}\right.$ $\left.\left\{\mathrm{HC}\left(\mathrm{PPh}_{2}\right)_{3}\right\}\right],{ }^{10}$ the three silver atoms are arranged in a triangular array with the $\mathrm{Ag}-\mathrm{Ag}-\mathrm{Ag}$ angles close to $60^{\circ}$. $\mathrm{An}$ interesting comparison between the two structures $\left[\mathrm{Ag}_{3} \mathrm{~L}_{2}\right]^{3+}$ and $\left[\mathrm{Au}_{3} \mathrm{~L}_{2} \mathrm{Cl}\right]^{2+}$ reveals much larger intramolecular metalmetal distances for silver relative to gold. A similar observation has also been reported for $\left[\mathrm{Au}_{2}(\mathrm{dmpm})_{2}\right]^{2+}[\mathrm{dmpm}=$ bis(dimethylphosphino)methane] and its silver analogue ${ }^{16}$ where the longer $\mathrm{Ag}-\mathrm{Ag}$ distance $\left\{3.041(2),\left[\mathrm{Ag}_{2}(\mathrm{dmpm})_{2}\right]\right.$ $\left.\left[\mathrm{PF}_{6}\right]_{2} ;{ }^{16} 3.028(2) \AA,\left[\mathrm{Au}_{2}(\mathrm{dmpm})_{2}\right]\left[\mathrm{ClO}_{4}\right]_{2}\right\}$ reflects lower relativistic effects in the $5 \mathrm{~s}$ orbital of $\mathrm{Ag}$ compared to the $6 \mathrm{~s}$ orbital of Au. The mixing of $6 \mathrm{~s}$, and to a lesser extent $6 \mathrm{p}_{z}$, with the $d_{\sigma}$ and $d_{\sigma^{*}}$ orbitals (here $d_{\sigma}$ and $d_{\sigma^{*}}$ refer to the bonding and antibonding combination of the $d_{z^{2}}$ orbitals) of $\mathrm{Au}_{2} \mathrm{P}_{4}{ }^{2+}$ will serve to provide a significant bonding interaction in the ground state and is responsible for the short $\mathrm{Au}-\mathrm{Au}$ distance. The measured $\mathrm{Ag}-\mathrm{Ag}$ distances of 3.1618(5)$3.2228(9) \AA$ in 2 , which are even larger than that found in $\left[\mathrm{Ag}_{2}(\mathrm{dppm})_{2}\right]\left[\mathrm{NO}_{3}\right]_{2}[d(\mathrm{Ag}-\mathrm{Ag})=3.085(1) \AA],{ }^{17}$ suggest the absence of metal-metal interaction in this trinuclear silver(I) complex.

Fig. 3(a) and $(b)$ show the respective UV/VIS absorption spectra of 1 and 2 in acetonitrile. Previous spectroscopic 


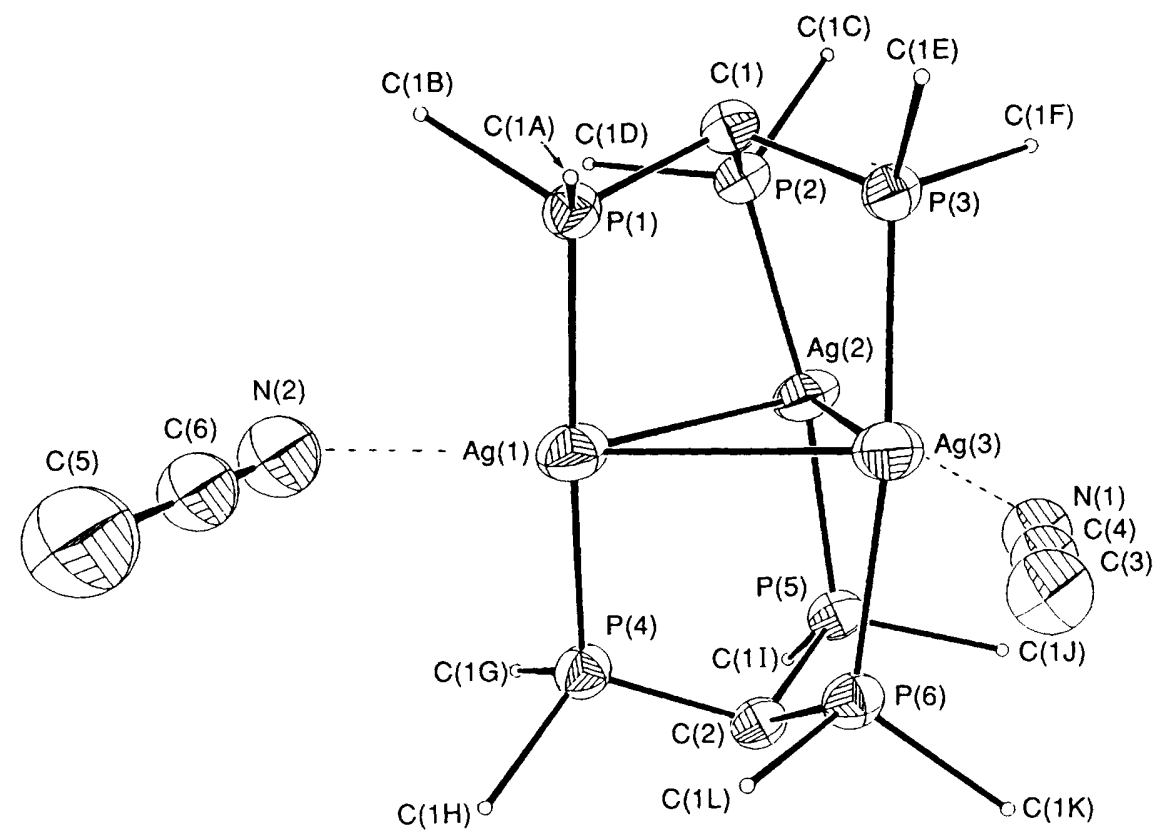

Fig. 2 ORTEP plot of the $\left[\mathrm{Ag}_{3} \mathrm{~L}_{2}\right]^{2+}$ cation with atomic numbering. Only the ipso carbons of the phenyl rings (of arbitrary radius) are shown for clarity

Table 5 Selected interatomic distances $(\AA)$ and angles $\left(^{\circ}\right)$ in $\left[\mathrm{Ag}_{3} \mathrm{~L}_{2}\right]\left[\mathrm{ClO}_{4}\right]_{3} \cdot 2 \mathrm{MeCN}$ with e.s.d.s in parentheses

$\begin{array}{lclr}\mathrm{Ag}(1)-\mathrm{Ag}(2) & 3.2228(9) & \mathrm{Ag}(2)-\mathrm{P}(5) & 2.429(1) \\ \mathrm{Ag}(1)-\mathrm{Ag}(3) & 3.1618(5) & \mathrm{Ag}(3)-\mathrm{P}(3) & 2.464(1) \\ \mathrm{Ag}(1)-\mathrm{P}(1) & 2.430(1) & \mathrm{Ag}(3)-\mathrm{P}(6) & 2.485(1) \\ \mathrm{Ag}(1)-\mathrm{P}(4) & 2.430(1) & \mathrm{Ag}(1)-\mathrm{N}(2) & 3.161(6) \\ \mathrm{Ag}(2)-\mathrm{Ag}(3) & 3.172(1) & \mathrm{Ag}(3)-\mathrm{N}(1) & 2.592(4) \\ \mathrm{Ag}(2)-\mathrm{P}(2) & 2.427(1) & & \\ \mathrm{Ag}(2)-\mathrm{Ag}(1)-\mathrm{Ag}(3) & 59.58(2) & \mathrm{Ag}(3)-\mathrm{Ag}(2)-\mathrm{P}(1) & 95.46(3) \\ \mathrm{Ag}(2)-\mathrm{Ag}(1)-\mathrm{P}(1) & 91.10(3) & \mathrm{Ag}(3)-\mathrm{Ag}(2)-\mathrm{P}(1) & 84.16(3) \\ \mathrm{Ag}(2)-\mathrm{Ag}(1)-\mathrm{P}(1) & 85.12(3) & \mathrm{P}(2)-\mathrm{Ag}(2)-\mathrm{P}(1) & 171.04(4) \\ \mathrm{Ag}(3)-\mathrm{Ag}(1)-\mathrm{P}(1) & 84.16(3) & \mathrm{Ag}(1)-\mathrm{Ag}(3)-\mathrm{Ag}(3) & 61.17(2) \\ \mathrm{Ag}(3)-\mathrm{Ag}(1)-\mathrm{P}(1) & 94.80(3) & \mathrm{Ag}(1)-\mathrm{Ag}(3)-\mathrm{P}(1) & 90.59(3) \\ \mathrm{P}(1)-\mathrm{Ag}(1)-\mathrm{P}(1) & 176.08(4) & \mathrm{Ag}(1)-\mathrm{Ag}(3)-\mathrm{P}(1) & 80.49(3) \\ \mathrm{Ag}(1)-\mathrm{Ag}(2)-\mathrm{Ag}(3) & 59.26(1) & \mathrm{Ag}(2)-\mathrm{Ag}(3)-\mathrm{P}(1) & 78.80(3) \\ \mathrm{Ag}(1)-\mathrm{Ag}(2)-\mathrm{P}(1) & 82.53(3) & \mathrm{Ag}(2)-\mathrm{Ag}(3)-\mathrm{P}(1) & 90.60(3) \\ \mathrm{Ag}(1)-\mathrm{Ag}(2)-\mathrm{P}(1) & 89.62(3) & \mathrm{P}(3)-\mathrm{Ag}(3)-\mathrm{P}(1) & 168.59(4) \\ & & & \end{array}$
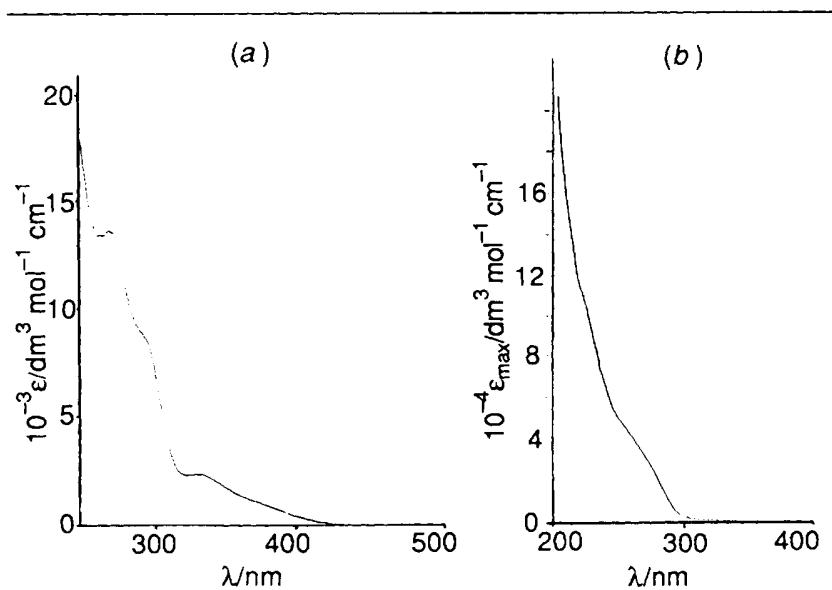

Fig. 3 UV/VIS absorption spectra of $(a)\left[\mathrm{Au}_{3} \mathrm{~L}_{2} \mathrm{Cl}\right]^{2+}$ and $(b)$ $\left[\mathrm{Ag}_{3} \mathrm{~L}_{2}\right]^{3+}$ in acetonitrile at room temperature

works ${ }^{2 a .18}$ showed that bonding interaction between two $\mathrm{d}^{10}$ bis- or tris-(phosphine)metal ions would lead to a red shift in the $d_{\sigma^{*}} \longrightarrow p_{\sigma}$ transition energy. $\dagger$ The close resemblance of the electronic absorption spectrum of the silver complex with that of the free ligand suggests the absence of a low energy $d_{\sigma^{*}} \longrightarrow$ $p_{\sigma}$ transition. For $\left[\mathrm{Au}_{3} \mathrm{~L}_{2} \mathrm{Cl}\right]^{2+}$, the absorption bands at 290 and $270 \mathrm{~nm}$, with their large $\varepsilon_{\max }$ values and their absence in $\left[\mathrm{Au}\left(\mathrm{PR}_{3}\right)_{2}\right]^{+},{ }^{19}$ are undoubtedly due to the spin-allowed $d_{\sigma^{*}} \longrightarrow p_{\sigma}$ transition. The observation of $d_{\sigma^{*}} \longrightarrow p_{\sigma}$ transition bands in $\left[\mathrm{Au}_{3} \mathrm{~L}_{2} \mathrm{Cl}\right]^{2+}$ but not in $\left[\mathrm{Ag}_{3} \mathrm{~L}_{2}\right]^{3+}$ would mean that the metal-metal interaction in the former is much stronger than that in the latter, in accordance with the X-ray crystallographic data described above. A direct comparison of the electronic spectral data between $\left[\mathrm{Au}_{3} \mathrm{~L}_{2} \mathrm{Cl}\right]^{2+}$ and $\left[\mathrm{Au}_{2}(\mathrm{dppm})_{2}\right]^{2+2 c, 4 a}$ is complicated by the fact that co-ordination of $\mathrm{Cl}^{-}$to gold could significantly perturb the $d_{\sigma^{*}} \longrightarrow p_{o}$ band. ${ }^{15}$ Besides the absorption bands at 290 and $270 \mathrm{~nm}$, there are also some broad absorptions in the $300-450 \mathrm{~nm}$ region. According to previous work by Mason and co-workers, ${ }^{15,18 d}$ such absorption bands could come from the $\left(d_{\delta^{*}}, d_{\pi^{*}}\right) \longrightarrow p_{\sigma}$ transition. Excitation of a degassed acetonitrile solution of $\left[\mathrm{Au}_{3} \mathrm{~L}_{2} \mathrm{Cl}\right]^{2+}$ at $300-400 \mathrm{~nm}$ results in photoluminescence centred at $537 \mathrm{~nm}$ with a luminescence quantum yield of $(1.0 \pm 0.1) \times 10^{-3}$. The excitation and emission spectra are shown in Fig. 4. The absence of the $\mathrm{d}_{\sigma^{*}} \longrightarrow \mathrm{p}_{\sigma}$ transition in the excitation spectrum suggests that the emitting state is probably not $\left[\left(\mathrm{d}_{\sigma^{*}}\right)\left(\mathrm{p}_{\sigma}\right)\right]$ in origin. An emission lifetime of $11 \mu$ s which is relatively insensitive to the concentration of the gold complex is obtained at room temperature. The presence of a relatively long-lived excited state suggests the emitting state probably arises from an electronic triplet state which originates from transition between the $6 \mathrm{p}$ and $5 \mathrm{~d}$ orbitals. It is interesting that the emission energies of the excited states of $\left[\mathrm{Au}_{2}(\mathrm{dppm})_{2}\right]^{2+}$ (emission $\lambda_{\max }=575$ $\mathrm{nm})^{2 c, 4 a}$ and the present $\left[\mathrm{Au}_{3} \mathrm{~L}_{2} \mathrm{Cl}\right]^{2+}$ systems are similar. Recent spectroscopic studies ${ }^{2 a}$ on $\left[\mathrm{Au}_{2}(\mathrm{dmpm})_{3}\right]^{2+}$ and $\left[\mathrm{Au}_{3}(\mathrm{dmmp})_{2}\right]^{3+}$ indicate that the lowest electronic excited state of polymetallic gold(I) systems is likely to be ${ }^{3}\left[\left(\mathrm{~d}_{\delta^{*}}\right)\left(\mathrm{p}_{\pi}\right)\right]$ in origin.

The phosphorescent state of $\left[\mathrm{Au}_{3} \mathrm{~L}_{2} \mathrm{Cl}\right]^{2+*}$ in acetonitrile is found to undergo facile electron-transfer quenching with pyridinium acceptors. The quenching rate constants are summarized in Table 6. An excited-state redox potential

+ The notations of $d_{\sigma}-d_{\sigma^{*}}, p_{\sigma}-p_{\sigma^{*}}$, and $s_{\sigma^{\prime}}-s_{\sigma^{*}}$ are adopted from the works of Harvey and Gray [ref. 18(c)] and Mason and co-workers [ref. 18(d)] to represent the bonding and antibonding combinations of $5 \mathrm{~d}_{z^{2}}$ (filled), $6 \mathrm{p}_{z}$, and $6 \mathrm{~s}$ orbitals. It is quite likely that the $\mathrm{p}_{\sigma}$ orbital is not a pure metal-centred orbital but rather substantially mixed with the $\pi^{*}$ orbital of the phosphine ligand. 
Table 6 Rate constants for the quenching of $\left[\mathrm{Au}_{3} \mathrm{~L}_{2} \mathrm{Cl}\right]\left[\mathrm{ClO}_{4}\right]_{2}$ by pyridinium acceptors in $0.1 \mathrm{~mol} \mathrm{dm}^{-3}\left[\mathrm{NBu}_{4}\right] \mathrm{PF}_{6}$ acetonitrile solution at $298 \mathrm{~K}$

\begin{tabular}{|c|c|c|c|c|}
\hline Quencher $^{a}$ & $E\left(\mathrm{~A}^{+/ 0}\right)^{b} / \mathrm{V}$ & $10^{-9} k_{\mathrm{q}} / \mathrm{dm}^{3} \mathrm{~mol}^{-1} \mathrm{~s}^{-1}$ & $10^{-9} k_{\mathrm{q}}{ }^{c} / \mathrm{dm}^{3} \mathrm{~mol}^{-1} \mathrm{~s}^{-1}$ & $(R T / F) \ln k_{\mathrm{q}}{ }^{\prime d} / \mathrm{V}$ \\
\hline 4-Cyano- $N$-methylpyridinium & -0.67 & 5.6 & 12.7 & 0.60 \\
\hline 4-Methoxycarbonyl- $N$-methylpyridinium & -0.78 & 4.9 & 9.6 & 0.59 \\
\hline 4-Amido- $N$-methylpyridinium & -0.93 & 3.1 & 4.4 & 0.57 \\
\hline 3-Amido- $N$-ethylpyridinium & -1.14 & 1.2 & 1.4 & 0.54 \\
\hline$N$-Ethylpyridinium & -1.36 & 0.19 & 0.19 & 0.49 \\
\hline 4-Methyl- $N$-methylpyridinium & -1.49 & 0.0086 & 0.0086 & 0.41 \\
\hline 2,6-Dimethyl- $N$-methylpyridinium & -1.52 & 0.0058 & 0.0058 & 0.40 \\
\hline
\end{tabular}

${ }^{a}$ All pyridinium acceptors are hexafluorophosphate salts. ${ }^{b}$ Potentials quoted $v s$. saturated calomel electrode (SCE). ${ }^{c} k_{\mathrm{q}}{ }^{\prime}$ is the rate constant corrected for the diffusion rate constant of $1 \times 10^{10} \mathrm{dm}^{3} \mathrm{~mol}^{-1} \mathrm{~s}^{-1} \cdot{ }^{d} R$ is the gas constant, $T$ is the absolute temperature and $F$ is the Faraday constant.

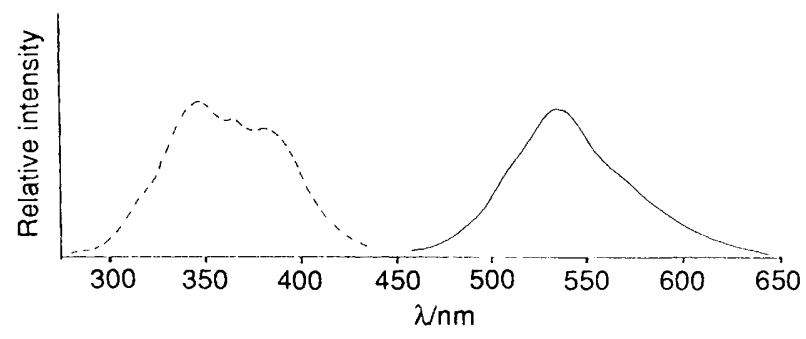

Fig. 4 Excitation (-- ) and emission spectra (-) of a degassed acetonitrile solution of $\left[\mathrm{Au}_{3} \mathrm{~L}_{2} \mathrm{Cl}\right]^{2+}$ at room temperature

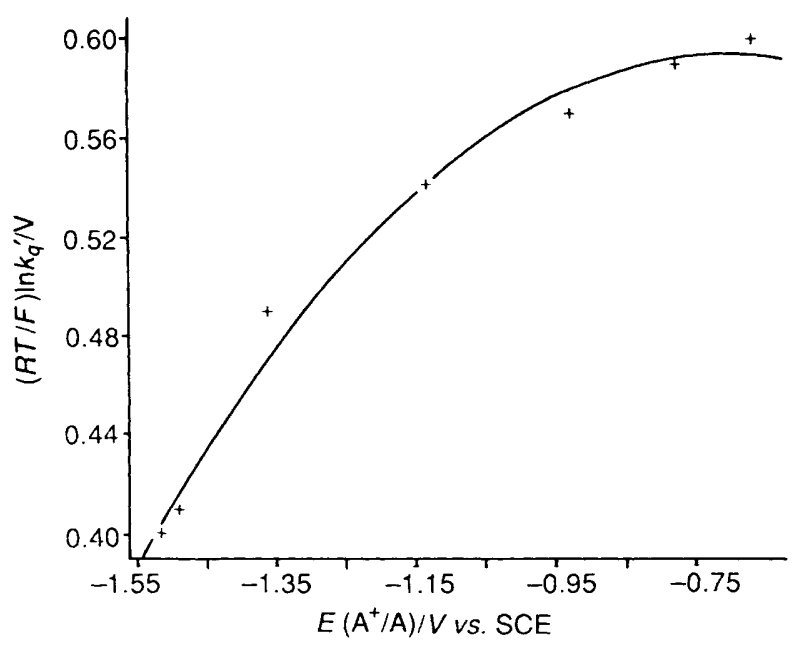

Fig. 5 Plot of $(R T / F) \ln k_{\mathrm{q}}^{\prime}$ versus $E\left(\mathrm{~A}^{+/ 0}\right)$ for the electron-transfer quenching of $\left[\mathrm{Au}_{3} \mathrm{~L}_{2} \mathrm{Cl}\right]\left[\mathrm{ClO}_{4}\right]_{2}$ by pyridinium acceptors $\left(\mathrm{A}^{+}\right)$in degassed acetonitrile: $(-)$ calculated; $(+)$ experimental

$E\left[\mathrm{Au}_{3} \mathrm{~L}_{2} \mathrm{Cl}^{3+/ 2+*}\right]$ of $-1.6(2) \mathrm{V}$ vs. saturated sodium chloride calomel electrode (SSCE) $[\lambda=0.95(10) \mathrm{eV}, R T \ln K \kappa \mathrm{v}=$ $0.57(10) \mathrm{V} v$ s. SSCE] has been obtained by three-parameter, non-linear least-squares fits to equation $(2)^{20}$ where $k_{\mathrm{q}}{ }^{\prime}$ is the

$$
(R T / F) \ln k_{\mathrm{q}}{ }^{\prime}=(R T / F) \ln K \kappa v-\left[\lambda(1+\Delta G / \lambda)^{2} / 4\right]
$$

rate constant corrected for diffusional effects, $K=k_{\mathrm{d}} / k_{-\mathrm{d}}$ which is approximately $1-2 \mathrm{dm}^{3} \mathrm{~mol}^{-1}, k_{\mathrm{d}}$ is the diffusion-limited rate constant in acetonitrile which is taken to be $1.0 \times 10^{10} \mathrm{dm}^{3}$ mol $^{-1} \mathrm{~s}^{-1}, \kappa$ is the transmission coefficient, $v$ is the nuclear frequency, $\lambda$ is the reorganization energy for electron transfer, and $\Delta G$, the standard free-energy change of the reaction, is given by equation (3) for oxidative quenching, where $\omega_{r}$ and $\omega_{p}$ are

$$
\Delta G(\mathrm{~V})=E^{\prime}\left[\mathrm{Au}^{(n+1)+/ n+*}\right]-E^{\circ}\left(\mathrm{Q}^{+/ 0}\right)+\omega_{\mathrm{p}}-\omega_{\mathrm{r}}
$$

work terms for bringing reactants or products to the mean separation for reaction. The work term associated with the
gold(I) complex and a pyridinium acceptor is $0.01-0.03 \mathrm{eV}$. This contribution is neglected in the analysis of the electron-transfer rate data. The close agreement between the theoretical curve with the experimental data in Fig. 5 is in accordance with the fact that the photoreactions are outer-sphere electron-transfer in nature. Similar excited-state redox potentials and reorganization energies are also observed for the structurally related $\left[\mathrm{Au}_{2}(\mathrm{dppm})_{2}\right]^{2+},\left[\mathrm{Au}_{2}(\mathrm{dmpm})_{2}\right]^{2+}$ and $\left[\mathrm{Au}_{3}(\mathrm{dmmp})_{2}\right]^{3+}$ systems. $^{2 a, c}$

\section{Acknowledgements}

We acknowledge financial support from the Croucher Foundation and the University of Hong Kong and the National Science Council (NSC) of Taiwan. H.-K. Y. acknowledges the receipt of a Croucher Foundation Studentship, administered by the Croucher Foundation. C.-M. C. thanks NSC and the National Taiwan University for a visiting professorship.

\section{References}

1 A. W. Maverick, J. S. Najdzionek, D. MacKenzie, D. G. Nocera and H. B. Gray, J. Am. Chem. Soc., 1983, 105, 1878.

2 (a) V. W. W. Yam, T. F. Lai and C. M. Che, J. Chem. Soc., Dalton Trans., 1990, 3747; (b) C. M. Che, W. T. Wong, T. F. Lai and H. L. Kwong, J. Chem. Soc., Chem. Commun., 1989, 243; (c) C. M. Che, H. L. Kwong, C. K. Poon and V. W. W. Yam, J. Chem. Soc., Dalton Trans., 1990, 3215

3 A. Vogler and H. Kunkely, Chem. Phys. Lett., 1988, 150, 135.

4 (a) C. King, J. C. Wang, N. I. Md. Khan and J. P. Fackler, jun., Inorg. Chem., 1989, 28, 2145; (b) N. I. Md. Khan, C. King, D. D. Heinrich, J. P. Fackler, jun. and L. C. Porter, Inorg. Chem., 1989, 28, 2150.

5 A. L. Balch, E. Y. Fung and M. M. Olmstead, J. Am. Chem. Soc., $1990,112,5181$.

6 See, for example, $(a)$ K. R. Kyle, C. K. Ryu, J. A. DiBenedetto and P. C. Ford, J. Am. Chem. Soc., 1991, 113, 2954; (b) A. Vogler and H. Kunkely, J. Am. Chem. Soc., 1986, 108, 7211; (c) A. Vogler and H. Kunkely, Chem. Phys. Lett., 1989, 158, 74; (d) P. D. Harvey, F. Adar and H. B. Gray, J. Am. Chem. Soc., 1989, 111, 1312; (e) M. Henary and J. I. Zink, J. Am. Chem. Soc., 1989, $111,7407$.

7 (a) J. A. Osborn and G. G. Stanley, Angew. Chem., Int. Ed. Engl., 1980, 19, 1025; (b) A. A. Arduini, A. A. Bahsoun, J. A. Osborn and C. Voelker, Angew'. Chem., Int. Ed. Engl., 1980, 19, 1024; (c) J. A Osborn, G. G. Stanley and P. H. Bird, J. Am. Chem. Soc., 1988, 110 2217 ; (d) J. A. Clucas, M. M. Harding, B. S. Nicholls and A. K. Smith, J. Chem. Soc., Chem. Commun., 1984, 319.

8 International Tables for $X$-Ray Crystallography, Kynoch Press, Birmingham, 1974, vol. 4.

9 B. A. Frenz, Enraf-Nonius Structure Determination Package, SDP User Guide, Enraf-Nonius, Delft, 1985.

10 C. E. Briant, R. G. Smith and D. M. P. Mingos, J. Chem. Soc., Chem. Commun., 1984, 586.

11 (a) C. M. Che, H. K. Yip, D. Li, S. M. Peng, G. H. Lee, Y. M. Wang and S. T. Liu, J. Chem. Soc, Chem. Commun., in the press; $(b)$ P. Y. Cheung and T. F. Lai, unpublished work.

12 J. A. Clucas, M. M. Harding, B. S. Nicholls and A. K. Smith, J. Chem. Soc., Dalton Trans., 1985, 1835.

13 H. Schmidbaur, A. Wohlleben, U. Schubert, A. Frank and G. Huttner, Chem. Ber., 1977, 110, 2751. 
14 L. C. Porter, N. I. Md. Khan, C. King and J. P. Fackler, jun., Acta Crystallogr., Sect. C, 1989, 45, 947.

15 H. R. C. Jaw, M. M. Savas, R. D. Rogers and W. R. Mason, Inorg. Chem., 1989, 28, 1028.

16 H. H. Karsch and U. Schubert, Z. Naturforsch., Teil B, 1982, 37, 186.

17 D. M. Ho and R. Bau, Inorg. Chem., 1983, 22, 4073

18 (a) W. Ludwig and W. Meyer, Helv. Chim. Acta, 1982, 65, 934; (b)

J. V. Caspar, J. Am. Chem. Soc., 1985, 107, 6718; (c) P. D. Harvey and H. B. Gray, J. Am. Chem. Soc., 1988, 110, 2145; (d) H. R. C. Jaw, M. M. Savas and W. R. Mason, Inorg. Chem., 1989, 28, 4366.

19 H. R. C. Jaw and W. R. Mason, Inorg. Chem., 1989, 28, 4370.

20 C. R. Bock, J. A. Connor, A. R. Gutierrez, T. J. Meyer, D. G. Whitten, B. P. Sullivan and J. K. Nagle, J. Am. Chem. Soc., 1979, 101 4815 .

Received 2nd July 1991; Paper 1/03292E 